\title{
Kualiti Kerja dalam Organisasi: Tinjauan dari Perspektif Pengurusan Islam
}

\author{
Work Quality in Organization: An Islamic Management Perspective
}

\author{
MASITAH IDRIS*, WAN FARIZA ALYATI WAN ZAKARIA, AHMAD SUNAWARI LONG \\ \& NOZIRA SALLEH ${ }^{1}$
}

\begin{abstract}
Management is a tool to improve quality of work and its relationship with the success of organisation therefore very fundamental. It begins with the power system, process of planning, prosedure and rules which can provide excellent contribution to the organization. This article will discuss some basic principle of management to improve the quality of work performance according to Islamic perspective. These fundamental principles include values such as insaniyyah (humanity), tawhid (unity), shūra (consultation) and istiqamah (steadfastness) in every action. It emphasises on attaining spiritual success through deligence in work of excellence. It means to get the best quality of work through both spiritual and material satisfaction whether by the employer and also the employee. This paper also discusses other elements that contribute to improve quality of work in Islamic perspective in order to achieve organisational success such as al-niyyah (having purpose), amanah (integrity), time management, cadl (justice/balance) and tacāwun (cooperation). Highly committed employee who combined all these elements will make great contribution to the organisation. Therefore, it is significant to stress the relevant relationship between all elements with quality of work within the Islamic perspective. Some elements which differentiates Islamic management with conventional management in general were also discussed in comparative manner to highlight the benefits of Islamic management to the overall well being of the employer and the employee as well as the organisation as a whole.
\end{abstract}

Keywords: Islamic management, Islamic organization, management, performance management, work quality

Pengurusan merupakan satu medium di dalam organisasi untuk mengurus manusia secara sistematik bagi membolehkan matlamat dan organisasi tersebut dicapai. Kepincangan di dalam pengurusan boleh menimbulkan masalah dan boleh melambatkan gerak kerja organisasi dan boleh menjejaskan kualiti kerja. Fokus perbincangan pengurusan dari perspektif Islam adalah memfokuskan manusia itu sendiri sebagai objek untuk diurus secara fizikal dan rohani secara

\footnotetext{
${ }^{1}$ Masitah Idris*(corresponding author), Ph.D. candidate at Centre for Akidah and Global Peace, Faculty of Islamic Studies, Universiti Kebangsaan Malaysia, 43600 BANGI, Selangor, Malaysia, email: masitahidris87@gmail.com; Wan Fariza Alyati Wan Zakaria, Ph.D., senior lecturer at Centre for Akidah and Global Peace, Faculty of Islamic Studies, Universiti Kebangsaan Malaysia, 43600 BANGI, Selangor, Malaysia, email: aufaa@ukm.edu.my; Ahmad Sunawari Long, Ph.D., assoc. professor at Centre for Akidah and Global Peace, Faculty of Islamic Studies, Universiti Kebangsaan Malaysia, 43600 BANGI, Selangor, Malaysia, email: aslong@ukm.edu.my; Nozira Salleh, Ph.D., senior lecturer at Centre for Akidah and Global Peace, Faculty of Islamic Studies, Universiti Kebangsaan Malaysia, 43600 BANGI, Selangor, Malaysia, email: aziera@ukm.edu.my.
} 
holistik dan sempurna. Semakin teratur sesebuah pengurusan organisasi, semakin berkualiti kerja yang dihasilkan. Kualiti kerja merupakan satu ukuran kecemerlangan di dalam pengurusan dan dapat dilihat di dalam nilai dan amalan bekerja seseorang. Perbincangan kualiti kerja dari perspektif Islam berkait rapat dengan aspek kecemerlangan. Kecemerlangan ini merujuk kepada mardhatillah (keredaan Allah) dan mencapai kecemerlangan di dunia dan akhirat kelak. Teras kepada kepada kualiti kerja dan kecemerlangan ini adalah pembinaan sahsiah dan akhlak yang unggul dalam diri pekerja. Selain itu, kerja yang berkualiti juga akan memberi kesan kepada kecemerlangan sesebuah organisasi, seterusnya menjadi penanda aras kepada kejayaan pentadbiran dan pengurusan khususnya dalam organisasi Islam.

\section{Pengurusan Islam}

Menurut Muhammad Al-Buraey (1986), pengurusan ialah menyelaraskan tenaga manusia untuk mencapai matlamat kelompok sebagai makhluk sosial yang perlu berinteraksi antara satu sama lain. Justeru, pengurusan Islam merupakan proses penting bagi mengendalikan manusia dan organisasi demi mencapai matlamat bekerja berlandaskan al-Quran dan al-Sunnah. Ilhamie (2001) pula mendefinisikan pengurusan Islam ialah sebagai satu sistem untuk mengurus kehidupan manusia dengan bersumberkan falsafah dan prinsip-prinsip Islam yang lengkap. Sistem pengurusan Islam bertujuan untuk mewujudkan perkhidmatan yang cekap dan sempurna, keadilan, sosial, jaminan keselamatan, kestabilan serta keamanan dan kemakmuran masyarakat. Objektif asas pengurusan Islam ialah menjadikan manusia sebagai fokus utama dengan merujuk kepada fungsi manusia diciptakan iaitu sebagai khalifah dan juga sebagai hamba Allah SWT. Firman Allah di dalam Surah al-Dhariyat (51:56) bermaksud "Dan (ingatlah) Aku tidak menciptakan jin dan manusia melainkan untuk mereka menyembah dan beribadat kepadaku".

Menurut Auni (n.d), fungsi manusia sebagai khalifah merupakan tanggungjawab yang besar untuk mengurus semua kejadian di muka bumi bagi menjamin kesejahteraan dan kebajikan manusia serta pembangunan sumber-sumber alam secara bermanfaat. Fungsi manusia sebagai hamba pula merujuk kepada pengabdian manusia sepenuhnya dan meletakkan segala usaha untuk mencapai keredhaan Allah. Kedua-dua fungsi ini menjadikan manusia sebagai makhluk yang istimewa dalam kalangan makhluk ciptaan Allah kerana manusia diberikan tanggungjawab yang besar dan amanah dalam mengendalikan dan memanfaatkan fungsi dan matlamat kejadian mereka. Oleh itu, tanggungjawab pengurusan ini merupakan amanah yang sudah sebati dalam diri manusia. Bertitik tolak dari pengertian tentang asal kejadian manusia inilah matlamat pengurusan Islam dibentuk dan dimajukan.

Prinsip-prinsip asas di dalam Pengurusan Islam telah terbukti memberi impak positif terhadap pengurusan, perancangan, pengawalan atau penilaian majikan di dalam organisasi bagi meningkatkan kualiti kerja pekerja. Terdapat beberapa prinsip asas Pengurusan Islam yang memberi kesan lebih efektif serta dapat membantu meningkatkan kualiti kerja pekerja di dalam organisasi antaranya ialah pengurusan berasaskan nilai Insaniyyah, nilai Tawhidik, Shura dan budaya Istiqamah (komitmen tinggi). Prinsip pertama iaitu nilai Insaniyyah merupakan prinsip yang menekankan peranan yang perlu dimainkan oleh pekerja samada pekerja atasan mahupun bawahan iaitu mereka perlu menerapkan sifat keinsanan dalam mengurus tadbir sesuatu perkara. Penciptaan manusia dengan fitrah yang suci bersih perlu dibangunkan potensi-potensi yang ada di dalam diri manusia supaya menjadi manusia berkualiti. Asas-asas kehambaan terhadap Allah SWT perlu diterapkan dalam diri manusia seperti taat setia, tunduk dan patuh kepada setiap perintah dan larangan Allah SWT. Justeru, pekerja yang mempunyai prinsip Insaniyyah ini pasti akan melaksanakan tugas dan amanah dengan sempurna kerana yakin dengan kehendak dan ketetapan Allah SWT sejak azali lagi (Hasan al-Banna 2013).

Prinsip pengurusan Islam kedua iaitu pengurusan berasaskan nilai Tawhidik pula menekankan pengurusan berasaskan keyakinan kepada kewujudan dan keesaan Allah, komitmen yang tinggi terhadap syariat Islam dan pelaksanaan amalan-amalan pengurusan yang 
bersumberkan kepada ilmu berasaskan iman sebagai asas-asas falsafah bagi pengurusan Islam (Fadzila Azni 2010). Secara umum, pengurusan berasaskan nilai Tawhidik ini bertitik tolak daripada tasawur Islam bersumberkan kepada ilmu naqli dan aqli secara bersepadu bagi membentuk etika kerja Islam sama ada dari segi sikap mahupun nilai hidup individu pekerja itu sendiri. Selain itu, prinsip pengurusan Tawhidik juga menitikberatkan amalan pengurusan berpandukan kepada konsep itqan dan ihsan. Konsep itqan sangat berkait rapat bagi menghasilkan budaya kerja yang berkualiti, istiqamah, dan tekun dalam melaksanakan sesuatu tugasan yang diberikan dan melakukan sesuatu kerja kerana Allah. Konsep itqan menjadi lebih mantap jika diperkukuhkan lagi dengan konsep ihsan dalam memberi perkhidmatan yang terbaik apabila wujud suatu keyakinan bahawa Allah sentiasa mengawasi pekerjaan dan melihat setiap apa yang dilakukan oleh hamba-hamba-Nya walau di mana jua berada (Muhammad Faisal \& Mohd Rizal, n.d). Hubungan secara horizontal ini amat perlu dititikberatkan bagi menghasilkan kualiti kerja yang mantap dan berterusan dalam kalangan kakitangan dalam sesebuah organisasi.

Ilhamie (2001) menjelaskan bahawa implikasi prinsip Tawhidik dalam pentadbiran dan pengurusan kepada setiap pekerja di dalam organisasi Islam antaranya ialah:

1. Umat Islam akan bersifat terbuka dan berpandangan jauh kerana setiap manusia adalah sama sahaja dan tidak perlu takut kepada mana-mana kuasa selain dari Allah SWT.

2. Insan yang soleh mempunyai sifat merendah diri dan tawaduk, tidak bersikap sombong, angkuh dan bongkak dan tidak lupa daratan, sentiasa bersyukur dengan nikmat Allah dapat diwujudkan.

3. Menjadi pekerja yang beramanah, rajin, cekap, jujur, berdisiplin dan bertanggungjawab dalam melaksanakan tugas kerana pekerja percaya bahawa mereka tidak akan menempah kejayaan melainkan mereka mengikut perintah Allah. Pekerja yang berdisiplin akan patuh kepada jadual kerja, peraturan dan menghormati masa.

4. Tidak akan mudah putus asa apabila berlaku musibah dan kegagalan. Pekerja akan percaya sepenuhnya kepada Allah SWT. yang menentukan kesudahan segala perbuatan manusia malah mereka akan belajar dari kesilapan lalu.

5. Sabar, mempunyai keazaman dan kesungguhan yang tinggi.

6. Redha, tidak dengki, tamak dan iri hati. Ini kerana mereka percaya bahawa kejayaan dan kegagalan adalah kehendak Allah. Manusia hanya mampu melakukan perancangan dan melaksanakan sahaja.

7. Patuh kepada peraturan dan undang-undang yang ditetapkan oleh Allah dan menolak daripada melakukan dosa. Ini kerana mereka percaya bahawa manusia akan mendapat balasan atas setiap perbuatan mereka sama ada di dunia mahupun di akhirat.

Prinsip pengurusan Islam ketiga pula menekankan dan mengamalkan konsep shura di dalam pengurusan dan pentadbiran sesebuah organisasi. Menurut Fadzila Azni (2010), pengamalan shura adalah untuk mencapai tiga matlamat utama iaitu matlamat pertama, penetapan falsafah pengurusan berpandukan al-quran dan al-sunnah. Kedua, pengutamaan kepada melahirkan pemimpin, pentadbir dan pengurus yang berakhlak unggul dan berkemahiran tinggi. Ketiga, penjaminan amalan pengurusan yang bertujuan mencapai kesejahteraan dunia dan akhirat (al-falah). Ketiga-tiga matlamat ini menggambarkan tiga komponen penting dalam pengurusan berasaskan shura iaitu falsafah pengurusan, watak pengurus dan amalan pengurusan. Integrasi komponen-komponen prinsip pengurusan Shura inilah yang menjadi asas kepada pengurusan berasaskan Tauhid. Ia bertitik tolak daripada usaha memenuhi amanah keinsanan di antara Allah selaku Pencipta dan manusia selaku hamba dan khalifah Allah. Amanah keinsanan ini hanya dapat dicapai menerusi amal soleh yang diasaskan oleh prinsip syura. Hubungan secara vertical dalam pengurusan Shura melengkapkan lagi kepentingan bekerja dengan menitikberatkan hubungan sesama manusia bagi menghasilkan kerja yang bekualiti. Selain itu, konsep shura bukan sahaja mendidik kakitangan supaya bekerja dengan penuh 
amanah, cekap, rajin dan bertanggungjawab malah turut menekankan hubungan dan semangat kerjasama sesama manusia bagi menghasilkan kerja dan perkhidmatan yang cemerlang di dunia dan juga di akhirat.

Prinsip pengurusan keempat iaitu menekankan budaya istiqamah atau komitmen tinggi yang memainkan peranan penting dalam memastikan kecemerlangan pekerja di dalam organisasi. Noralai dan Norhasni (2010) menyatakan komitmen adalah sikap dan perlakuan untuk bekerja kuat, pengekalan dan kesetiaan dalam sesebuah organisasi, penerimaan dan kepercayaan terhadap matlamat organisasi, penglibatan dan penyertaan dalam pekerjaan, ikatan emosi dan identifikasi terhadap organisasi yang membantu meningkatkan kecekapan dan keberkesanan organisasi. Definisi ini selaras dengan maksud Istiqamah seperti dinyatakan di dalam Ensiklopedia Islam (1998) iaitu sebagai berpendirian teguh pada keyakinan yang benar, tetap, berlanjutan dan mempercayai. Ini akan menjadikan seseorang yangg beristiqamah akan bekerja dengan tekun, berusaha dengan giat dan gigih berjuang untuk mencapai cita-cita. Selain itu, pekerja yang mempunyai komitmen yang tinggi lebih cenderung untuk menghasilkan kerja yang berkualiti seterusnya memberi kesan kepada kecemerlangan organisasi.

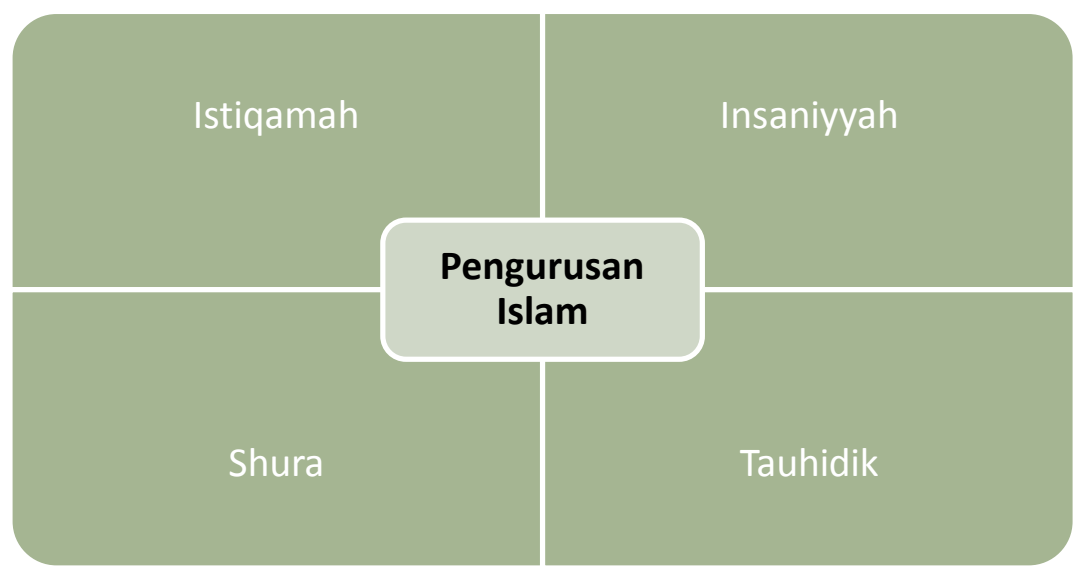

Pada asasnya, prinsip-prinsip Pengurusan Islam sebagaimana yang dinyatakan di atas menjadi penanda aras kepada pembentukkan pekerja yang berakhlak dan cemerlang meliputi rohani dan jasmani sekiranya diaplikasi di dalam setiap praktis pengurusan sesebuah organisasi. Ini kerana nilai-nilai yang digarap di dalam Pengurusan Islam ini mampu menangani cabaran dan realiti pada masa kini dan pada masa akan datang. Pekerja yang mempraktiskan amalan pengurusan Islam ini juga berupaya membantu organisasi untuk mencapai matlamat dan objektif yang ditetapkan serta mendapat keredhaan Allah di dalam setiap pekerjaan mereka. Selain itu, impak pengurusan Islam bukan hanya bersifat materialistik sahaja tetapi merangkumi impak dwi dimensi iaitu memperoleh kejayaan sebenar (al-falah) di dunia dan juga di akhirat kelak.

\section{Kualiti Kerja di dalam Islam}

Menurut Kamus Dewan Edisi Keempat (2010), kualiti ialah darjah kecemerlangan yang pada kebiasaannya adalah tinggi atau bermutu. Mustafa (1994: 103) mentakrifkan kualiti sebagai kepercayaan, keyakinan dan norma yang berfungsi sebagai tenaga penggerak yang menentukan perlakuan, tindakan dan proses organisasi. Nilai kualiti pula didefinisikan sebagai kepercayaan, keyakinan dan norma yang berfungsi sebagai tenaga penggerak yang menentukan perlakuan, tindakan dan proses organisasi dan seterusnya memberi kesan kepada kecemerlangan sesebuah organisasi. Mohd Tap (1991: 49) mendefinisikan kualiti sebagai kepuasan hati pelanggan dan menurut keperluan yang ditetapkan. Justeru, kualiti kerja dapat ditakrifkan sebagai amalan bekerja seseorang menurut nilai dan prinsip yang digariskan bagi menghasilkan kerja yang bermutu tinggi dan cemerlang. 
Perbincangan berkaitan kualiti kerja dapat dilihat di dalam kaedah pengurusan sesebuah organisasi berpandukan kepada nilai atau amalan bekerja seseorang. Persoalan kualiti di dalam Islam mempunyai hubungan dengan mencapai kecemerlangan. Kecemerlangan ini merujuk kepada mardhatillah (keredhaan Allah). Teras kepada kualiti dan kecemerlangan ini ialah pembinaan sahsiah pekerja yang unggul dan bermutu tinggi. Bertitik tolak dari prinsip-prinsip asas di dalam pengurusan Islam membawa kepada perbincangan mengenai nilai atau amalan bekerja dari perspektif Islam. Menurut Sharifah Hayaati (2010), Islam menganjurkan nilai-nilai untuk dijadikan panduan dan amalan dalam menghasilkan kualiti kerja yang terbaik yang seharusnya diamalkan oleh semua kakitangan samada pihak pengurusan atasan atau bawahan. Nilai-nilai ini hendaklah diserap dan diaplikasikan sebagai budaya kerja seharian bagi mencapai piawaian kualiti kerja menurut acuan Islam bagi memenuhi tuntutan kerohanian, kebendaan dan intelektual. Tuntutan material adalah untuk memenuhi kehendak keduniaan manakala tuntutan kerohanian yang perlu diambil berat menjadi kayu ukur bagi membina aspek-aspek positif dan konstruktif untuk membangunkan organisasi. Oleh yang demikian, setiap pekerjaan dalam Islam mestilah berteraskan tauhid kepada Allah SWT.

Untuk menjadikan sesuatu kerja itu berkualiti, konsep dan nilai yang dianjurkan dalam Islam perlu disemai dan dipraktikkan dalam urusan seharian supaya akhirnya ia dapat diserap dan diaplikasikan sebagai budaya kerja yang berkualiti dalam pengurusan. Nilai-nilai ini akan menjadi asas untuk menentukan kualiti kerja seseorang pekerja sama ada cemerlang atau sebaliknya. Menurut Tengku Sarina \& Fadillah (2016), nilai-nilai tersebut ialah pertama, setiap perbuatan baik hendaklah disertakan dengan niat yang suci dan ikhlas kerana Allah SWT. Kedua, Islam menghendaki penganutnya melakukan sesuatu lebih dari apa yang dikehendaki mengikut peraturan yang telah ditentukan oleh Allah SWT melalui konsep ihsan. Ketiga, nabi Muhammad SAW sebagai qudwah hasanah yang par-excellence. Justeru, adalah menjadi tanggungjawab orang Islam melakukan tugas secara cemerlang, cekap dan mahir. Keempat, seseorang Muslim hendaklah bermuhasabah tentang kerja yang telah dilakukan dan sentiasa berusaha untuk memperbaiki kelemahan diri serta melakukan yang terbaik pada masa akan datang.

Selain itu, Shaharom (1999: 27) menerusi karya beliau yang bertajuk Pengurusan Islam dan Pembangunan Manusia telah menggariskan beberapa perkara asas yang menjadi teras di dalam bekerja. Perkara asas yang dimaksudkan ialah pertama, niat bekerja semata-mata kerana Allah. Kedua, kerja yang dilakukan tidak akan menghalang pekerja untuk menunaikan tugas asasi (fardu ain). Ketiga, kerja itu hendaklah menjadi tuntutan oleh syarak dan keempat, matlamat bekerja hendaklah semata-mata untuk mendapat keredhaan Allah. Selain Shaharom, Mustafa (1994: 48) turut mengemukakan perkara-perkara asas di dalam pengurusan Islam. Asas-asas yang dikemukakan ialah pertama, falsafah dan nilai yang jelas iaitu jawatan merupakan amanah daripada Allah dan adalah menjadi tugas dan tanggungjawab pekerja sebagai khalifah Allah di muka bumi ini. Kedua, pengurusan dan tenaga kerja mempunyai akhlak yang mulia, mempunyai kemahiran, mempunyai komitmen terhadap organisasi dan mempunyai semangat persaudaraan Islam. Ketiga, sistem dan amalan dalam rangka Syariah Islamiah iaitu adil, saksama, efektif, shura dan menilai diri sendiri.

Kerja berkualiti yang menjadi amalan kerja bersama apabila diperkukuhkan dengan sistem, proses, prosedur dan peraturan yang jelas akan membentuk budaya kerja yang cemerlang. Ia merujuk kepada tatacara dan etika kerja yang baik di kalangan kakitangan pengurusan atasan dan pekerja bawahan. Di antara tatacara bekerja yang baik termasuklah rajin, gigih, berdaya cipta, kreatif, inovatif, semangat kerjasama, kerja berpasukan, integriti, berdisiplin dan bersikap berusaha untuk meningkatkan prestasi diri dan kerja. Budaya kerja yang cemerlang inilah yang diharapkan sebagai manifestasi dari pengurusan kualiti kerja. Justeru, di dalam artikel ini penulis akan membincangkan beberapa nilai atau amalan bekerja yang boleh membantu meningkatkan kualiti kerja seperti matlamat bekerja, amanah, menghargai masa, adil dan bekerjasama. Pertama, matlamat bekerja untuk mendapat keredhaan Allah SWT. Islam menetapkan setiap amalan yang dilakukan hendaklah disertakan niat kerana Allah SWT dan niat itu hendaklah tidak melanggar 
syariat yang ditetapkan oleh agama Islam. Selain itu, setiap amalan yang diniatkan kerana Allah juga akan dikira sebagai ibadah dan akan mendapat keredhaan Allah. Syarat niat hendaklah ikhlas dan tulus semata-mata kerana Allah sebagai pengabdian seorang hamba kepada tuannya dalam mencari keredhaan-Nya. Niat juga merupakan realisasi ketauhidan dalam pengertian Allah SWT sebagai satu-satunya tumpuan amal pengabdian. Tanpa niat yang sedemikian, amal soleh yang dilakukan tidak akan memberi keuntungan di akhirat. Rasulullah SAW bersabda yang bermaksud "Sesungguhnya setiap amalan berdasarkan niat dan sesungguhnya setiap orang mengikut apa yang dia niatkan". Implikasi niat terhadap amal seseorang ialah niat merupakan iltizam atau komitmen batin yang serius dan bersungguh-sungguh untuk melakukan sesuatu. Selain itu, niat juga membawa kesan kepada kawalan dalaman agar amal dan perlakuan seseorang tidak terpesong dari tujuan asal sebagaimana yang telah diniatkan. Niat kerana Allah SWT turut memberi implikasi kepada kesedaran tentang Tuhan (God Consciousness) sejak memulakan sesuatu amalan dan berterusan sehingga ke akhirnya.

Islam menyifatkan bekerja sebagai salah satu instrumen dalam mencapai mardhatillah atau keredhaan Allah dan ia dituntut sepanjang masa. Tiga perkara utama untuk mendapat keredhaan Allah iaitu pertama, tauhid yang jelas kerana Allah. Kedua, syariat yang dijaga dan dipatuhi. Ketiga, akhlak yang dijaga dengan bersungguh-sungguh (Sharifah Hayaati 2010). Ketigatiga perkara ini perlu dijaga dan diamalkan oleh semua kakitangan dalam organisasi bagi menjamin mutu kerja yang berkualiti dan cemerlang. Justeru, matlamat bekerja di dalam Islam adalah untuk mendapat keredhaan Allah SWT dan juga memperoleh al-falah di dunia dan di akhirat. Matlamat kerja dalam Islam terbahagi kepada dua iaitu matlamat jangka panjang dan jangka pendek. Matlamat jangka panjang lebih tertumpu kepada menghayati cita-cita dan kesedaran mencari keredhaan Allah SWT dalam semua perkerjaan yang dilakukan dan ia dijadikan panduan dalam kehidupan manusia di dunia ini. Matlamat ini bukan sahaja menentukan tahap pencapaian dan kualiti diri di dunia bahkan di akhirat dan juga mencapai al-falah. Matlamat jangka pendek ialah merupakan produktiviti dan hasil kerja dalam bentuk material. Ia lebih kepada matlamat duniawi dan perlu diselaras dan diharmonikan dengan matlamat jangka panjang. Oleh itu, adalah tidak salah untuk mencapai matlamat duniawi selagi ia dipayungi oleh matlamat jangka panjang. Apa yang menjadi kesalahan adalah menumpukan usaha dan bekerja kepada pencapaian material semata-mata dengan mengetepikan aspek keredhaan Allah di dalam bekerja. Matlamat bekerja inilah yang membezakan pengurusan Islam dengan Barat. Di Barat, pengurusan kerja lebih tertumpu kepada aspek material semata-mata seperti memaksimumkan produktiviti, kualiti dan keuntungan semata-mata dan lebih banyak dipengaruhi oleh dimensi duniawi seperti kepuasan diri, keseronokan dan kemewahan sehingga tercetus teori Machiavelli iaitu matlamat menghalalkan cara sebagai prinsip dan pegangan hidup mereka. Budaya bekerja sebegini adalah dilarang di dalam Islam kerana memisahkan urusan organisasi dari kesedaran keagamaan. Kecemerlangan yang dicipta bukan kecemerlangan sejati kerana ia tidak berpaksikan kepada matlamat sebenar sebagaimana yang dianjurkan di dalam Islam (Auni n.d: 18). Firman Allah SWT di dalam Surah al-Baqarah 2:207 yang bermaksud "Dan antara manusia ada yang mengorbankan dirinya kerana mencari keredhaan Allah semata-mata, dan Allah pula amat belas kasihan akan hamba-hambaNya" dan Surah al-Lail 92:20-21 yang bermaksud "Hanyalah mengharapkan keredhaan Tuhan-Nya yang Maha Tinggi, dan demi sesungguhnya ia akan berpuas hati (pada hari akhirat) dengan mendapat segala yang diharapkannya".

Imam Ibn Khathir (2000) menjelaskan golongan yang berpuas hati di akhirat kelak ialah golongan yang menggunakan apa yang ada pada dirinya ke jalan kebaikan serta mengerjakan suruhan Allah dan meninggalkan larangan-Nya. Oleh itu, dapat dikatakan golongan yang mengharapkan keredhaan Allah semata-mata merupakan golongan dijamin oleh Allah untuk mendapat kepuasan yang hakiki di akhirat kelak. Hakikatnya, seseorang pekerja perlu mendetikkan di dalam hati supaya setiap amal dan pekerjaan yang dilakukan adalah untuk Allah. Ia hanyalah untuk mendapat keredhaan daripada Allah. Sekiranya pekerjaan yang dilakukan mendapat keredhaan Allah, ia akan memberi implikasi kepada diri pekerja itu sendiri seperti 
ketenangan, berpuas hati, tidak gelisah, tidak bosan, tidak merasakan memikul beban yang berat dan tidak merasakan matlamat bekerja sukar dicapai. Ini merupakan ganjaran yang paling besar yang wajar diperolehi oleh setiap pekerja yang melakukan pekerjaan hanya untuk Allah.

Kedua, amanah. Maksud amanah dari segi bahasa ialah memenuhi atau kepercayaan dan dari segi istilah pula bermaksud melaksanakan apa yang telah diperintahkan oleh Allah kepada hamba-Nya. Menurut Mustafa (1994: 133), amanah merupakan sesuatu yang wajib dijaga dengan sebaiknya dan menyerahkannya kepada yang berhak menerimanya. Apabila seseorang gagal melaksanakan amanah, ini bermaksud dia telah melakukan khianat kerana matlamat amanah adalah untuk mencapai keadilan. Seorang pekerja yang beramanah akan menghasilkan keamanan dan kemakmuran kepada masyarakat. Amanah di kalangan pekerja akan menjamin kesejahteraan rakyat. Beramanah dalam kerja ialah menjalankan kerja dengan penuh tanggungjawab dan tekun serta mengikut peraturan yang ditetapkan. Terdapat dua unsur penting yang boleh membantu seorang pekerja bersifat amanah iaitu berpegang teguh kepada agama dan menghapuskan kepentingan diri sendiri. Amanah juga merupakan elemen penting untuk mengukuhkan nilai diri dan kerja seseorang pekerja Islam supaya menampilkan nilai kerja yang berkualiti dan baik dalam Islam. Setiap manusia akan dipertanggunjawabkan dengan amanah yang digalas di dunia dan akan dipersoalkan di akhirat nanti. Firman Allah di dalam Surah an-Nisa' 4:58 yang bermaksud "Sesungguhnya Allah menyuruh kamu supaya menyerahkan segala jenis amanah kepada ahlinya (yang berhak menerimanya), dan apabila kamu menjalankan hukum di antara manusia, (Allah menyuruh) kamu menghukum dengan adil. Sesungguhnya Allah dengan (suruhanNya) itu memberi pengajaran yang sebaik-baiknya kepada kamu. Sesungguhnya Allah sentiasa Mendengar, lagi sentiasa Melihat".

Ketiga, menghargai masa. Menghargai masa atau menggunakan masa dengan cekap dan semaksimum mungkin ketika bekerja merupakan salah satu unsur amalan bekerja di dalam Islam dan memberi kesan kepada tahap kualiti kerja pekerja. Pekerja yang menggunakan sepenuh masa bekerja dengan cekap dan sistematik berupaya menyiapkan kerja pada masa yang ditetapkan. Ini menggambarkan pekerja tersebut mempunyai ciri-ciri pekerja yang berkualiti dalam tanggapan majikan mereka. Selain itu, pekerja yang sentiasa menghargai masa bekerja juga turut memberi tanggapan positif terhadap imej dan personaliti mereka. Pekerja yang tidak menggunakan masa bekerja dengan betul akan memberi kerugian kepada organisasi dan akan menjejaskan imej pekerja itu sendiri dan organisasi. Ini mengakibatkan objektif dan matlamat organisasi sukar dicapai sebagaimana yang telah direncanakan. Firman Allah di dalam Surah Al-Asr 103: 1-3 yang bermaksud "Demi masa. Sesungguhnya manusia itu berada dalam kerugian. Kecuali orang yang beriman dan melakukan amalan yang salih serta saling berpesan supaya menjunjung agama yang benar dan saling berpesan supaya bersikap sabar".

Keempat, adil. Adil dan saksama mengikut Arahan Pekhidmatan Awam ialah setiap kakitangan wajib berlaku adil dan saksama terhadap orang ramai dan memberikan layanan yang teratur dan memuaskan. Konsep keadilan di dalam organisasi meliputi semua hal dan bidang, melibatkan peraturan, undang-undang, nilai, etika, pemilihan calon ke sesuatu jawatan, agihan kerja dan gaji. Pelantikan kakitangan perlu dijalankan secara adil dan tidak memilih kasih, tidak hipokrit, berkepentingan dan lain-lain nilai yang dianggap bertentangan dengan nilai murni (Mustafa 1994: 132). Selain itu, konsep keadilan juga melibatkan semua pihak bermula dengan pengurusan tertinggi sehingga kepada pekerja biasa. Adalah menjadi tanggungjawab pihak atasan untuk memberikan tugas yang bersesuaian dengan kemahiran seseorang dan memberikan ganjaran yang bersesuaian dengan hasil kerja mereka. Firman Allah di dalam Surah an-Nisa' 4: 57 yang bermaksud "Atau patutkah mereka dengki kepada manusia (Nabi Muhammad dan umatnya) disebabkan nikmat (pangkat Nabi dan agama Islam) yang telah diberikan oleh Allah kepada mereka dari limpah kurniaNya? Kerana sesungguhnya Kami telahpun memberi kepada keluarga Ibrahim: Kitab (agama) dan hikmat (pangkat Nabi) dan kami telah memberi kepada mereka kerajaan yang besar". 
Kelima, bekerjasama. Bekerjasama merupakan unsur yang penting di dalam melaksanakan tugas, melahirkan keharmonian, keamanan dan kemesraan di tempat kerja. Selain itu, melalui kerjasama akan meningkatkan hasil dan mutu kerja. Kerjasama dapat dilaksanakan dengan cara menjaga hubungan yang baik dan mempunyai sikap tolong-menolong, bantumembantu, kasih- mengasihi dan hormat-menghormati. Di antara ciri bekerjasama ialah melaksanakan tugas secara kolektif, mengutamakan idea secara kolektif yang menjamin kejayaan yang mantap dan mengutamakan mesyuarat dan merujuk kepada pakar dalam hal dan bidang yang rumit (Mustafa 1994: 139). Melalui kerjasama yang ditonjolkan oleh ahli organisasi akan memberi kepuasan kerja kepada seseorang untuk terus bekerja dengan lebih tekun dan bersemangat. Firman Allah di dalam surah Al-Maidah 5:2 yang bermaksud “. . . Dan tolong menolonglah kalian atas kebaikan dan ketaqwaan, dan janganlah tolong menolong atas dosa dan permusuhan. Sesungguhnya azab Allah amatlah pedih".

Melalui perbincangan di atas dapat dirumuskan bahawa nilai dan amalan bekerja di dalam organisasi memainkan peranan yang penting untuk membentuk pekerja yang bermutu, cemerlang dan berkualiti serta membantu untuk meningkatkan kualiti kerja pekerja. Ini kerana kecemerlangan sesebuah organisasi adalah bergantung kepada kualiti pekerjanya. Selain itu, nilai dan amalan bekerja yang telah dibincangkan juga berupaya membentuk disiplin dalam diri pekerja supaya mengikut peraturan-peraturan yang telah ditetapkan oleh organisasi dengan baik dan mampu membentuk budaya kerja yang cemerlang di kalangan pekerja. Islam telah memberi penekanan khusus tentang kepentingan mengamalkan nilai dan amalan bekerja yang betul dalam kehidupan seharian dan nilai-nilai Islam yang dibentuk di dalam bekerja perlu diamalkan sepanjang masa supaya sesebuah organisasi dapat diuruskan dengan cemerlang. Penerapan nilai dan amalan bekerja secara menyeluruh di dalam organisasi memberi kesan kepada pekerja untuk melakukan apa sahaja pekerjaan dengan sempurna dan bermatlamat untuk mendapat keredhaan Allah di dunia dan juga di akhirat.

\section{Rajah 1 Matlamat dan Falsafah Pengurusan Islam}

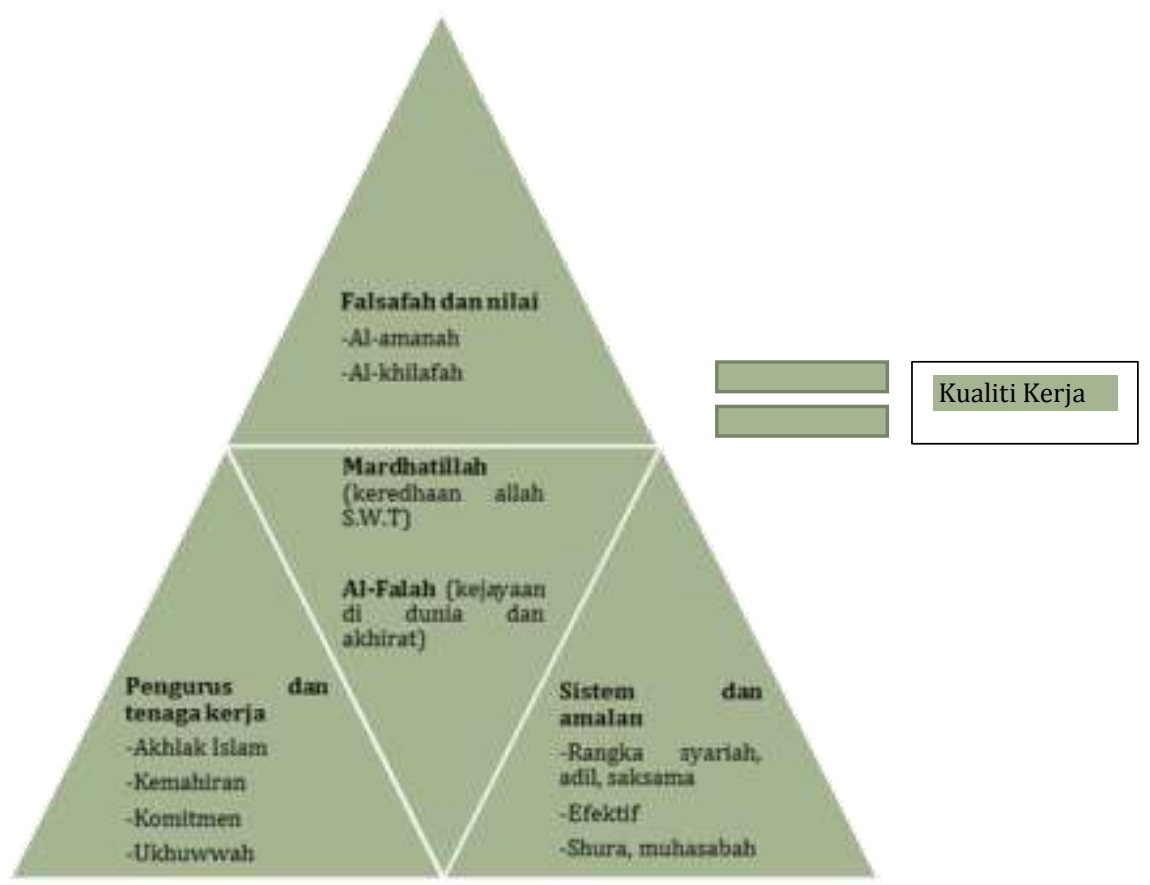




\section{Perbezaan Pengurusan Islam dan Pengurusan Konvensional}

Dari segi operasional, pengurusan Islam dilihat seolah-olah hampir sama dengan pengurusan konvensional. Akan tetapi, pada hakikatnya terdapat beberapa aspek yang menjadi asas kepada perbezaan sistem pengurusan Islam dan konvensional meliputi kerangka, konsep-konsep asas, epistemologi, matlamat dan falsafah pengurusan. Pengurusan Islam bersifat komprehensif dan berteraskan kepada falsafah tauhid bersumberkan al-quran dan al-sunnah (Mohiuddin 2012; Mohd Affandi 1992; Muhammad al-Bureay n.d.). Falsafah ini akan memberi impak kepada matlamat dan pelaksanaan pengurusan yang lebih holistik di dalam organisasi tanpa memisahkan nilai agama dan tidak mementingkan keuntungan material semata-mata. Pekerja yang berkualiti di dalam pengurusan Islam ialah pekerja yang mengamalkan nilai dan tatacara bekerja sebagaimana yang ditetapkan oleh syarak. Mereka juga sangat produktif dan berkeupayaan untuk menyumbang kepada kemajuan sesebuah organisasi dalam bentuk kuantitatif atau kualitatif. Hal ini berbeza dengan falsafah pengurusan konvensional yang mengasaskan teori pengurusan bersumberkan kepada individu seperti Karl Marx dan Maslow. Walaupun teori yang diasaskan oleh mereka telah diaplikasi di dalam pengurusan konvensional, tetapi ia masih tidak mampu dan gagal dalam membentuk etika pekerja yang mantap. Ini kerana pengurusan konvensional hanya menumpukan aspek fizikal atau material dan melihat manusia sebagai "haiwan ekonomi" yang mampu memberi keuntungan kepada organisasi dalam bentuk material seperti peningkatan produktiviti.

Seterusnya, jika dianalisis dari aspek konsep-konsep asas pengurusan Islam dan konvensional, terdapat beberapa perbezaan dari sudut pegangan asas dan fokus utama pengurusan. Asas di dalam pengurusan Islam ialah mengoptimakan tujuan penciptaan manusia sebagai hamba kepada Allah dan khalifah di dunia ini dengan melakukan segala perintah dan meninggalkan larangan. Pengurusan ke atas makhluk dijalankan secara komprehensif dan menyeluruh meliputi aspek pemikiran, spiritual, emosi, kemahuan dan fizikal manusia. Ini menunjukkan pengurusan Islam menekankan dwi dimensi iaitu melibatkan rohani dan jasmani pekerja. Pengurusan konvensional pula melihat manusia sebagai "alat" kepada pengeluaran yang membantu meningkatkan ekonomi industri dengan melakukan eksploitasi sumber untuk memenuhi kemahuan yang tidak terhad. Keadaan ini menggambarkan pengurusan konvensional memberi fokus kepada pengurusan fizikal manusia sahaja. Selain itu, perbezaan kedua-dua pengurusan ini dapat ditinjau dari aspek matlamat akhir di dalam pengurusan. Matlamat akhir pengurusan Islam ialah untuk mendapat keredhaan Allah dan mencapai kecemerlangan di dunia dan di akhirat kelak. Ini menjadi pendorong dan motivasi kepada pekerja untuk bekerja dengan lebih bersungguh-sungguh. Matlamat akhir pengurusan konvensional pula menumpukan kepada hasil kerja dalam bentuk kuantiti seperti memaksimumkan pengeluaran, memaksimumkan pendapatan dan memaksimumkan penggunaan. Semakin tinggi keuntungan yang diperolehi, semakin berjaya dan cemerlang sesebuah organisasi itu. Sudut pandang ini membuktikan pengurusan konvensional menggunakan sepenuhnya manusia sebagai alat pengeluaran dengan mengerah tenaga dan fizikal pekerja bagi memenuhi keperluan material dan fizikal (Fadzila Azni 2010; Mohamed, Abdul Kadir \& Nur Arfifah 2014).

Jadual 1 - Ringkasan perbezaan antara pengurusan Islam dan pengurusan konvensional

\begin{tabular}{|c|c|c|}
\hline & Pengurusan Islam & Pengurusan Konvensional \\
\hline Tujuan Pengurusan & $\begin{array}{l}\text { - Merangkumi pengurusan dari } \\
\text { aspek rohani dan fizikal/material } \\
\text { secara bersepadu } \\
\text { - Berfungsi sebagai satu } \\
\text { mekanisme untuk beribadah } \\
\text { kepada Allah untuk memenuhi }\end{array}$ & $\begin{array}{l}\text { - Penumpuan kepada pengurusan } \\
\text { fizikal/material } \\
\text { - Sebagai satu mekanisme bagi } \\
\text { mengikut arus semasa seperti } \\
\text { kemajuan, perubahan, sosial, } \\
\text { modenisasi, pertumbuhan }\end{array}$ \\
\hline
\end{tabular}




\begin{tabular}{|c|c|c|}
\hline & $\begin{array}{l}\text { fungsi manusia sebagai hamba } \\
\text { dan khalifah } \\
\text { - Melibatkan dimensi menegak } \\
\text { (hubungan dengan Allah) dan } \\
\text { dimensi mendatar (hubungan } \\
\text { sesama manusia) }\end{array}$ & $\begin{array}{l}\text { ekonomi dan penghapusan } \\
\text { kemiskinan } \\
\text { - Melibatkan dimensi mendatar }\end{array}$ \\
\hline Sumber ilmu utama & $\begin{array}{l}\text { - Dalil naqli (al-Quran dan hadith) } \\
\text { - Dalil 'aqli (Ijmak Ulama dan } \\
\text { Qiyas) }\end{array}$ & $\begin{array}{l}\text { - Pengasas/Individu yang } \\
\text { terangkum dalam falsafah } \\
\text { pengurusan konvensional (Karl } \\
\text { Marx, Maslow) }\end{array}$ \\
\hline \multirow[t]{2}{*}{ Konsep asas } & $\begin{array}{l}\text { Pegangan Asas } \\
\text { - Allah sebagai Pencipta } \\
\text { - Manusia hamba dan khalifah }\end{array}$ & $\begin{array}{l}\text { Andaian Asas } \\
\text { - Manusia sebagai alat pengeluaran } \\
\text { - keupayaan ekonomi penentu } \\
\text { kepada kemajuan dan } \\
\text { kecemerlangan }\end{array}$ \\
\hline & $\begin{array}{l}\text { Fokus utama pengurusan } \\
\text { - Manusia merangkumi elemen } \\
\text { rohani dan fizikal } \\
\text { - Penggunaan sumber mengikut } \\
\text { keperluan }\end{array}$ & $\begin{array}{l}\text { Fokus utama pengurusan } \\
\text { - Ekonomi } \\
\text { - Eksploitasi sumber untuk } \\
\text { memenuhi kemahuan yang tidak } \\
\text { terhad }\end{array}$ \\
\hline $\begin{array}{l}\text { Matlamat } \\
\text { Pengurusan }\end{array}$ & $\begin{array}{l}\text { - Mendapat keredhaan Allah } \\
\text { - Mencapai kejayaan di dunia dan } \\
\text { akhirat }\end{array}$ & $\begin{array}{l}\text { - Memaksimumkan pengeluaran } \\
\text { - Memaksimumkan pendapatan } \\
\text { - Memaksimumkan penggunaan }\end{array}$ \\
\hline
\end{tabular}

Merujuk kepada perbincangan di atas, dapat disimpulkan bahawa pengurusan merupakan satu mekanisme untuk mengurus manusia secara teratur dan sistematik bagi mencapai matlamat dan objektif sesebuah organisasi. Pengurusan Islam telah menggariskan beberapa beberapa prinsip asas untuk diapliksikan di dalam pengurusan seperti nilai Insaniyyah, nilai Tawhidik, Shura dan budaya Istiqamah (komitmen tinggi) yang sangat efektif untuk meningkatkan kualiti kerja. Pengurusan Islam bersifat komprehensif dan holistik merangkumi pengurusan dari aspek rohani dan fizikal ke atas pekerja. Prinsip asas yang digarap di dalam pengurusan Islam menjadi pemangkin untuk melahirkan pekerja yang seimbang dari aspek pemikiran, spiritual, emosi, kemahuan dan fizikal bertunjangkan kepada konsep tauhid yang menjadi pegangan utama setiap pekerja. Ini seterusnya akan membawa kepada lahirnya pekerja yang berkualiti, yang mengamalkan nilai dan amalan bekerja berpandukan ajaran Islam seperti bekerja kerana Allah SWT, amanah, adil, menghargai masa, bekerjasama dan sebagainya. Pekerja yang baik dan berkualiti akan berusaha menambah baik pencapaian organisasi dengan memberi sepenuh komitmen terhadap kerja yang dilakukan. Selain itu, pekerja yang berkualiti juga akan menetapkan objektif-objektif yang dipercayai olehnya akan memberi kesan positif kepada organisasi dalam suasana kerja yang penuh bersemangat. Kerangka konsep pengurusan Islam yang dibentuk hanyalah bertujuan untuk memperkasakan fungsi penciptaan manusia dwi dimensi sebagai hamba dan khalifah bagi mendapat keredhaan Allah dan mencapai kecemerlangan di dunia dan di akhirat kelak.

Perbezaan yang ketara dapat dilihat di dalam pengurusan konvensional yang mengeksploitasi peranan manusia sebagai "alat" bagi memenuhi kehendak fizikal dan material bagi tujuan peningkatan keuntungan pengeluaran dan pendapatan sesebuah negara. Walaupun kita tidak menafikan sistem pengurusan konvensional dilihat seperti kemas dan teratur dengan mewujudkan peringkat pengurusan seperti perancangan (planning), susun atur (organising), perjawatan (staffing), kepimpinan (leading) dan kawalan (controlling) dan turut mengamalkan nilai dan etika di dalam pengurusan tetapi ia lebih menjurus kepada memaksimumkan produktiviti, kualiti dan keuntungan semata-mata serta berlaku pemisahan nilai-nilai agama. Pemisahan nilai agama di dalam pengurusan konvensional menunjukkan pengurusan ini tidak dijalankan secara holistik kerana terdapat kelompongan dari aspek keperluan rohani dan 
spiritual manusia. Ini kerana agama merupakan pembentuk nilai, sikap dan tingkahlaku yang paling mantap kepada manusia. Faktor utama yang menjejaskan dan mengancam pengeluaran bukan disebabkan kelemahan teknologi secara keseluruhan tetapi disebabkan rapuhnya nilai integriti dan berlaku penyelewengan dalam pelbagai bentuk. Kepincangan sistem pengurusan dari mana-mana aspek akan menimbulkan ketidakseimbangan dalam pengurusan organisasi dan akan menjejaskan kualiti kerja dan memberi gambaran negatif terhadap imej organisasi tersebut. Bagi memantapkan lagi pengurusan Islam dalam meningkatkan kualiti kerja pada hari ini, penulis mencadang beberapa perkara seperti berikut:

1. Objektif dan matlamat organisasi dirangka berteraskan kepada nilai dan konsep Tawhidik yang betul.

2. Memupuk dan menerapkan nilai itqan dan ihsan dalam melaksanakan tugas. Pekerja yang mengamalkan nilai itqan dan ihsan akan sentiasa melakukan kerja dengan bersungguhsungguh walaupun tidak diawasi oleh ketua di mana sahaja mereka berada serta tidak mengharapkan penghargaan daripada manusia.

3. Nilai dan amalan bekerja dirangka bertepatan dengan syariat Islam dan mampu memberi kesan kepada kualiti kerja.

\section{References}

Al-Quran.

Auni, H. A. n.d. Pengurusan Islam: Potensi dan Cabaran. n.l: Darulfikir Sdn. Bhd.

Ensiklopedia Islam. 1998. Jilid. 5. Kuala Lumpur: Malaysian Encyclopedia Research Center Bhd.

Fadzila Azni, A. 2010. Kaedah Pengurusan Institusi-Institusi Pembangunan Berteraskan Islam di Malaysia. Shah Alam: Pusat Penerbitan Universiti (UPENA).

Hasan Al-Banna, M., Ab. Mumin A. G., \& Siti Arni, B. 2013. Sistem Pengurusan Islam Yang Berkualiti Mampu Menjamin Kepuasan Pekerja: Suatu Realiti dan Cabaran Masa Hadapan. Global Journal al-Thaqafah 3(1): 67-84.

Ibn Khathir. 2000. Tafsir al-Qur'an al-'Azim. Vol. 5. Beirut: Dar al-Ihya' al-Turath al 'Arabi.

Ilhamie, A. G. 2001. Pengurusan dari Perspektif Islam. Jurnal Syariah 9(2): 85-102.

Kamus Dewan. Edisi Keempat. 2010. Kuala Lumpur: Dewan Bahasa Dan Pustaka.

Mohamed, S., Nur Arfifah, A. S., \& Abdul Kadir, O. 2014. The understanding of Islamic management practices among Muslim managers in Malaysia. Asian Social Science 10(1): 189.

Mohd Affandi, H. 1992. The Tawhidic Approach in Management and Public Administrative: Concepts, Principles and Alternative Model. Kuala Lumpur: INTAN.

Mohd Tap Selleh. 1991. Nilai dan Etika Dalam Perkhidmatan Awam. Kuala Lumpur: INTAN.

Mohiuddin, G.M. Management views in Islamic literature: a conceptual analysis on the way of new management dimension. International Journal of Management 3: 411-424.

Muhammad al-Bureay. 1986. Islam Landasan Alternatif Pembangunan. Jakarta: CV. Rajawali.

Muhammad al-Bureay. n.d. Management \& Adminstration in Islam. n.l: n.p.

Muhamad Faisal, B., \& Mohd Rizal, M. n.d. Kualiti Perkhidmatan Menurut perspektif Islam. 1-16.

Mustafa Haji Daud. 1994. Pengurusan Islam. Kuala Lumpur. Utusan Publications \& Distributors Sdn. Bhd.

Noralai, I., \& Norhasni, Z. A. 2010. Tinjauan faktor-faktor yang mempengaruhi komitmen pekerja terhadap organisasi. Dinamika Sosial Ekonomi 6(1): 1-16.

Sharifah Hayaati, I. 2010. Etika Penjawat Awam Dari Perspektif Islam. Kuala Lumpur: Dewan Bahasa dan Pustaka.

Tengku Sarina, T. K., \& Fadillah, M. 2007. Keperluan motivasi dalam pengurusan kerja berkualiti dari perspektif pemikiran Islam. Jurnal Usuluddin 25: 103-124. 